\title{
BENTURAN ANTARA KREDITOR PRIVILEGE DENGAN KREDITOR PREFEREN PEMEGANG HIPOTEK KAPAL LAUT TERKAIT ADANYA FORCE MAJEURE
}

\author{
Fani Martiawan Kumara Putra \\ Fakultas Hukum Universitas Airlangga Surabaya \\ e-mail: fanimartiawan@gmail.com
}

\begin{abstract}
ABSTRAK
Lahirnya hak kebendaan akan melahirkan kreditor, kreditor yang terlahir akibat dari adanya jaminan kebendaan adalah kreditor preferen dimana kreditor preferen itu mempunyai berbagai ciri-ciri unggulan, antara lain yaitu didahulukannya pelunasan hutangnya daripada kreditorkreditor lain. Namun ciri istimewa ini akan tampak kabur saat berbenturan dengan kreditor privilege yang eksistensinya juga diatur dalam undang-undang. Benturan antara kreditor privilege dengan kreditor preferen ini melemahkan posisi kreditor preferen, hal ini terutama terkait dengan pelunasan hutang karena terjadinya force majeure, dan pembayaran jaminan oleh pihak asuransi. Hal ini dikarenakan pada saat terjadi force majeure, kreditor preferen sudah seyogyanya menjadi kreditor konkuren namun tetap memegang karakter sebagai kreditor preferen karena janji-janji dalam pembebanan hipotek kapal laut.
\end{abstract}

Kata Kunci: kreditor privilege, force majeure, asuransi, hipotek kapal laut.

\begin{abstract}
Property rights will engender creditors, creditors which are produced due to the existence of zakelijke zekerheid (property guarantee) are preferred creditors who has various superior characteristics, including the payment will be prioritized than other concurrent creditors. But the superior characteristics of the preferred creditors will looks weak when it crashed with privilege creditors which the existence are regulated in Law. The conflict between preferred creditors and privilege creditors makes the preferred creditors character become so weak, it is related to debt fulfillment because of force majeure and guarantee payment by the insurance company. This situation happened because when there was a force majeure, then the preferred creditors now should be just a concurrent creditors but they still hold the characters of preferred creditors because of the implication of the promises when the ship mortgage agreement made.
\end{abstract}

Keywords: privilege creditors, force majeure, insurance, ship mortgages.

\section{PENDAHULUAN}

Perkembangan dunia bisnis pada dewasa ini terus berkembang pesat, perkembangan itu juga tampak pada industri bisnis pelayaran. Perkembangan bisnis pelayaran ini dikarenakan begitu menariknya daya pikat akan profit yang dapat dihasilkan dari bisnis itu. Kepemilikan suatu kapal laut sebagai sarana transportasi laut yang utama adalah suatu hal yang penting dalam keseluruhan proses demi suksesnya bisnis di bidang pelayaran. Kepemilikan atas kapal laut hampir selalu didampingi dengan penjaminan, hal ini dikarenakan mahalnya harga kapal laut, dan juga sangat beresikonya kegiatan pelayaran itu.

Jaminan yang disediakan untuk kapal laut, adalah hipotek yang diatur dalam Pasal 1162 Burgerlijk Wetboek (selanjutnya disebut BW), hipotek adalah suatu hak kebendaan atas benda-benda tak bergerak, bertujuan untuk mengambil penggantian daripadanya bagi pelunasan suatu perikatan. Konstruksi hukum ini mengacu pada pembebanan pada benda tidak bergerak. Benda tidak bergerak tidak hanya atas kapal laut yang berukuran $20 \mathrm{~m}^{3}$, tetapi juga pada pembebanan atas tanah, namun hipotek atas tanah kini tidak berlaku lagi karena Buku II BW yang berkaitan dengan hipotek atas tanah telah dicabut dengan telah hadirnya Undang-Undang No. 4 Tahun 1999 tentang Hak Tanggungan. Perjanjian hipotek ini merupakan bentuk jaminan khusus yaitu perjanjian yang diikuti perjanjian tersendiri yang merupakan tambahan (accessoir) yang akan dikaitkan dengan perjanjian pokok (Sri Soedewi Masjchoen Sofwan, 
1982:37). Ini berarti kalau pihak yang bersangkutan tidak memenuhi kewajiban dari perikatannya, maka secara paksa, hukum dapat menyuruh jual lelang benda-benda milik orang tersebut guna mengganti pelunasan kewajiban perikatan yang dilalaikan itu (Moch. Isnaeni, 1996:32).

Dengan memahami karakter bagaimana kapal bekerja, di atas perairan, bukan merupakan hal yang tidak mungkin akan terjadinya suatu peristiwa yang tidak terduga, seperti hanyutnya kapal, tenggelamnya kapal, terbakarnya kapal, rusak beratnya kapal, dan peristiwa tak terduga lainnya yang dapat mengurangi atau bahkan menghilangkan nilai ekonomis dari kapal tersebut, dan pastinya hal ini dapat menimbulkan kerugian pada pihak kreditor. Seperti halnya pada saat penulisan tesis ini sedang berlangsung, di Negara Indonesia ini telah terjadi peristiwa tak tertuga yang memilih kapal laut sebagai mangsanya, ada yang memakan korban, ada pula yang tidak memakan korban jiwa, kecelakaan kapal tersebut antara lain adalah: 27 Agustus 2011, Kapal Motor Windu Karsa tenggelam di perairan Kolaka, Sulawesi Tenggara, dan menyebabkan 10 orang tewas; Pada 21 September 2011, Kapal Motor Sri Murah Rezeki tenggelam di perairan Nusa Lembongan, Klungkung, Bali, dan menyebabkan 14 orang tewas; 24 September 2011, Kapal Motor Tunggal Putri tenggelam di perairan Pulau Raas, Kepulauan Kangean, Sumenep, Madura, dan menyebabkan 13 orang tewas; 26 September 2011, Kapal Motor Marina Nusantara tenggelam di perairan Pulau Kadap, perairan Barito, Kalimantan Selatan; 28 September 2011, Kapal Motor Kirana IX terbakar di Pelabuhan Tanjung Perak, kapal laut tersebut terbakar, dan mengakibatkan sebanyak 8 penumpang tewas terinjak-injak di tengah kepanikan (Anggi Kusumadewi, http://nasional.vivanews.com/ news/read/250815-sebulan-ada-5-kecelakaan-kapal-salah-siapa- diakses tgl. 11/09/2012)

Untuk mencegah terjadinya kerugian yang besar, kerapkali para pelaku bisnis membebankan asuransi pada obyek jaminan, yang mana akan disepakati dan dicantumkan dalam bentuk awal berupa janji-janji yang tertuang dalam dokumen penjaminan kapal laut.

Hukum jaminan dengan segala perkembangannya, melahirkan beberapa keistimewaan yang mana juga bersumber pada $\mathrm{BW}$, salah satunya adalah kreditor privilege, yang mana hal ini juga merupakan suatu keistimewaan seperti halnya hak kebendaan dalam hal hukum jaminan ini. Dalam hukum jaminan, di antara orang-orang berpiutang yang mana diberikan keistimewaan, tingkatannya akan di atur menurut berbagai-bagai sifatnya hak-hak istimewa. Semakin dengan berkembangnya hal ini, maka semakin pula menimbulkan kenyamanan dan rasa percaya yang lebih bagi para pelaku bisnis dalam mencari dana segar untuk kegiatan bisnisnya melalui penjaminan, namun bukanlah hal yang tidak mungkin bahwa dari beberapa hak yang lahir tersebut dapat berbenturan. Termasuk dalam penyelesaian sengketa dan imbasnya pada pembagian santunan dalam pelunasan hutang.

Berdasarkan dari apa yang telah diuraikan tersebut di atas, permasalahan dalam penulisan ini adalah bilamana kapal laut musnah karena force majeure, bagaimanakah kedudukan pemegang hipotek kapal laut atas santunan yang dibayarkan oleh perusahaan asuransi mengingat adanya kreditor privilege.

\section{PEMBAHASAN \\ Preferensi Kreditor Pemegang Hipotek Kapal Laut}

Timbulnya hak kebendaan harus dengan melalui perjanjian accessoir yaitu perjanjian tambahan dari perjanjian awalnya (induknya), dengan kata lain, harus diperjanjikan terlebih dulu mengenai benda yang akan dijaminkan secara khusus (Pasal 1132 BW). Ciri-ciri yang istimewa yang dimiliki oleh hak jaminan kebendaan yaitu: 1 . Bersifat mutlak. Hak itu dapat ditegakkan terhadap siapa pun juga, termasuk rekan-rekan sekontrak atau pihak-pihak lain yang ikut terkait di kemudian hari; 2. Droit de Suite. Hak tersebut akan tetap mengikuti (melekat) bendanya ke tangan siapa pun benda itu berada. Jika benda tersebut berpindah tangan, maka yang bersangkutan juga wajib menghormati hak kebendaan tersebut; 3 . Terdapat preferensi (Pasal 1132 BW). Jika obyek jaminan telah laku dilelang, maka kreditor preferen harus didahulukan pelunasannya daripada piutang kreditor-kreditor lainnya (konkuren); 4. Mengandung asas prioritas. Hak kebendaan yang lahir terlebih dahulu akan didahulukan untuk pelunasan piutangnya daripada hak kebendaan yang mana lahir belakangan, yang tentunya pelunasan piutangnya akan dibayar belakangan. Asas prioritas ini digunakan apabila terjadi benturan antara sama-sama pemegang hak kebendaan; 5. Mengandung asas separatis. Dalam hal terjadi kepailitan, pada umumnya, pemegang hak kebendaan itu terpisah dari kreditor konkuren lainnya. Serta pelaksanaan eksekusi benda jaminan dapat dilakukan secara langsung (parate eksekusi); 6 . Terdapat gugat kebendaan (zakelijk actie). Pemegang hak kebendaan dapat menggugat apabila haknya ada yang mengganggu, misalnya: penuntutan kembali, penggantian kerugian, pemulihan keadaan semula. 
Mengenai ciri-ciri hak kebendaan, Sri Soedewi Machsoen mengemukakan bahwasanya sekurangnya ditemukan 10 (sepuluh) ciri hak kebendaan, antara lain: Hukum kebendaan merupan hukum yang bersifat memaksa; Hak kebendaan dapat dipindah tangankan; Individualiteit; Totaliteit; Onsplitsbaarheid atau asas tidak dapat dipisahkan; Prioriteit; Asas Vermenging atau percampuran; Asas Publicitiet; Asas perlakuan yang berbeda atas kebendaan bergerak dan kebendaan tidak bergerak; Adanya sifat perjanjian dalam setiap pengadaan atau pembentukan suatu hak kebendaan (Gunawan Widjaja, op.cit.:205).

Seperti halnya dengan jaminan kebendaan, maka kreditor penerima hipotek yang dalam hal ini adalah pemegang hipotek atas kapal laut memiliki kepastian hukum serta kedudukan yang cukup aman dan kuat dalam rangka untuk memperoleh kembali pelunasan piutangnya apabila sewaktu-waktu debitor melakukan wanprestasi. Kreditor pemegang hipotek atas kapal laut memiliki hak kebendaan yang lahir pada saat didaftar dalam suatu register umum dan mempunyai ciri-ciri istimewa. Sebagaimana diungkapkan oleh Moch Isnaeni bahwa perjanjian jaminan hipotek yang sering menyertai pemberian fasilitas kredit perbankan, akan melahirkan hak-hak kebendaan bagi kreditornya. Hak kebendaan ini memiliki ciri-ciri yang tangguh misalnya hak itu dapat ditegakkan terhadap siapa pun (mutlak), ada droit de suite, memiliki preferensi, berazas prioritas dan mempunyai prinsip spesialitas (Moch. Isnaeni, 1996:179).

Hipotek sebagai suatu jaminan kebendaan adalah jaminan yang obyeknya benda yang mana benda ini milik debitor yang akan diikat secara khusus dan memerlukan pendaftaran, dan akan menimbulkan hak kebendaan yang sifatnya mutlak atau zakelijke zekerheidsrechten, dan juga memberikan kedudukan preferen kepada para kreditor pemegangnya sehingga hak kebendaan tersebut dapat memiliki keunggulankeunggulan bila dibandingkan dengan hak jaminan lainnya termasuk juga jaminan perorangan. Timbulnya hak kebendaan harus melalui perjanjian accessoir yaitu perjanjian tambahan dari perjanjian awalnya (induknya), dengan kata lain, harus diperjanjikan terlebih dulu mengenai benda yang akan dijaminkan secara khusus (Pasal 1132 BW), seperti dikemukakan oleh Sri Soedewi bahwa, jaminan kebendaan adalah suatu jaminan yang berupa hak mutlak atas suatu benda, yang punya ciri-ciri mempunyai hubungan langsung atas benda tertentu, dapat dipertahankan terhadap siapa pun juga, selalu mengikuti bendanya atau droid de suite dan dapat dialihkan (Sri Soedewi Machsoen Sofwan, 1980:46-47).
Selebihnya mengenai ciri-ciri hak kebendaan, ditambahkan oleh Gunawan Widjaja yang mengutip Sri Soedewi Machsoen bahwa sekurangnya ditemukan 10 (sepuluh) ciri hak kebendaan, antara lain: Hukum kebendaan merupan hukum yang bersifat memaksa; Hak kebendaan itu dapat untuk dipindah tangankan; Individualiteit; Totaliteit; Onsplitsbaarheid atau asas tidak dapat dipisahkan; Prioriteit; Asas Vermenging percampuran; Asas Publicitiet; Asas perlakuan yang berbeda atas kebendaan bergerak dan kebendaan tidak bergerak; Adanya sifat perjanjian di dalam setiap pengadaan atau pembentukan hak kebendaan (Gunawan Widjaja, 2005:205)

Hipotek sebagai suatu hak kebendaan dari suatu jaminan kebendaan juga mewakili sifat-sifat khusus dari hak kebendaan diatas, dijabarkan oleh Gunawan Widjaja dalam bukunya, yaitu: Hipotek itu bersifat memaksa (absolute); Hipotek itu dapat beralih atau dipindahtangankan; Bersifat individualitet; Bersifat menyeluruh (totaliteit); Tidak dapat dipisahkan atau onsplitsbaarheid; Hipotek berjenjang (ada prioritas yang satu atas yang lainnya); Haruslah diumumkan; Mengikuti bendanya (droit de suite) (Pasal 1136 ayat 2, Pasal 1198 BW); Bersifat mendahulu (droit de preference) (Pasal 1132 BW); Hipotek sebagai Jura In Re Alinea (Gunawan Widjaja, 2005:207).

Berdasarkan dari uraian di atas, salah satu sifat istimewa yang melekat pada hipotek adalah Droit de Preference, dari sinilah timbulnya preferensi untuk didahulukan pelunasan hutangnya, ini merupakan salah satu sifat khusus yang dimiliki hak kebendaan dalam bentuk jaminan kebendaan. Hak ini lahir dari ketentuan Pasal 1132 BW, 1133 BW dan 1134 BW. Dalam Pasal 1132 BW ditegaskan bahwa, Kebendaan tersebut menjadi jaminan bersama-sama bagi semua orang yang mengutangkan kepadanya; pendapatan penjualan itu dibagi-bagi menurut keseimbangan, yaitu menurut besar kecilnya piutang masing-masing, kecuali apabila di antara para kreditor itu ada alasanalasan yang sah untuk didahulukan.

Begitu pula dalam Pasal 1133 BW, Hak untuk didahulukan di antara para kreditor terbit dari hak istimewa, dari gadai dan dari hipotek. Tentang gadai dan hipotek di atur dalam Bab XX dan Bab XXI. Dan juga Pasal 1134 BW menegaskan, Hak istimewa ialah suatu hak yang oleh undang-undang diberikan kepada seorang kreditor sehingga tingkatannya lebih tinggi daripada kreditor lainnya, semata-mata berdasarkan sifat piutangnya. Gadai dan hipotek adalah lebih tinggi daripada hak istimewa, kecuali dalam hal-hal tertentu dimana oleh undang-undang ditentukan untuk berlaku sebaliknya. 
Pemberian hipotek yang mana melahirkan hak mendahulu ini dapat ditemukan dalam rumusan Pasal 1162 BW, 1178 BW, dan 1198 BW, dimana Pasal 1162 BW mengungkapkan, Hipotek adalah suatu hak kebendaan atas benda-benda tak bergerak, untuk mengambil pergantian daripadanya bagi pelunasan suatu perikatan.

Juga Pasal 1178 BW yang menegaskan tentang kuasa menjual, bahwa diperkenankanlah pada kreditor hipotek pertama, untuk pada waktu berdirinya jaminan hipotek, dengan tegas minta diperjanjikan, bahwa jika uang pokok tidak dilunasi semestinya, atau jika bunga yang terutang tidak dibayar, ia secara mutlak akan dikuasakan menjual persil yang diperikatkan di muka umum, untuk mengambil pelunasan uang pokok, maupun bunga serta biaya, dari pendapatan penjualan itu.

Pasal 1198 BW kemudian menjelaskan tingkat pelunasan piutangnya, kreditor yang mempunyai suatu hipotek yang telah dibukukan, dapat menuntut hak nya atas benda tak bergerak yang diperikatkan dalam tangan siapa pun benda itu berada, untuk ditetapkan tingkatannya dan juga untuk menerima pembayaran menurut tertibnya pembukuan.

Dan juga dalam hal tingkatan kreditor hipotik, dijabarkan dalam Pasal 1181 BW, 1182 BW, dan 1183 BW. Pasal 1181 BW ini yang kemudian melahirkan asas prioritas untuk hak kebendaan hipotek, tingkatan orang-orang berpiutang hipotek ditentukan menurut tanggal pembukuan mereka, dengan tidak mengurangi kekecualian-kekecualian tersebut dalam kedua pasal berikut. Mereka yang mana dibukukan pada hari yang sama, bersama-sama untuk mempunyai suatu hipotek yang bertanggal sama, tak peduli pada jam mana pembukuan telah dilakukan, biarpun jam itu dicatat oleh pegawai penyimpan hipotek.

Dari ketentuan pasal-pasal yang telah dijabarkan di atas, dapat diketahui bahwa hipotek diberikan sebagai jaminan pelunasan hutang yang mana bersifat mendahulu mengenai pelunasan hutang. Dalam hal ini Gunawan Widjaja berpendapat bahwasanya hipotek sebagai jaminan pelunasan hutang mempunyai hak mendahulu dengan cara menjual sendiri benda yang dijaminkan dan memperoleh pelunasan sejumlah nilai hipotek, atau nilai piutang kreditor, yang mana yang lebih rendah (Gunawan Widjaja, 2005:222).

Dari dasar-dasar dan juga keistimewaan tersebut lah kreditor hipotek itu kemudian terlahir sebagai kreditor preferen, bukan sebagai kreditor konkuren, dan juga sepanjang hutang atau kredit yang dijamin dengan hipotek masih berjalan, benda jaminan pada dasarnya masih dapat dibebani lagi oleh debitor, hal ini sesuai Pasal 61 ayat 1 UU Pelayaran ditegaskan bahwa kapal laut dapat dibebani lebih dari 1 (satu) hipotek. Dan bilamana debitor menjaminkan lagi benda jaminan hipotek, maka pemegang hipotek pertama mempunyai kedudukan yang lebih tinggi atau kuat, dengan pengertian bahwa pemegang hipotek pertama yang harus didahulukan pelunasan hutangnya daripada pemegang hipotek selanjutnya (Pasal 315 WvK). Karena dalam hal jaminan kebendaan sebagai jaminan khusus, kreditor hipotek berada pada kreditor preferen, bukan kreditor konkuren.

Prinsip hukum jaminan bahwa hak preferen dari kreditor pemegangnya (kreditor preferen) terhadap harta kekayaan yang telah sah diikat oleh suatu hak jaminan kebendaan adalah diutamakan atau Droit de Preference. Konsekuensi dari berlakunya prinsip hukum ini adalah jika dilakukan eksekusi penjualan atau eksekusi lelang atas harta kekayaan tersebut, maka kreditor preferenlah yang mana berhak untuk pertamakalinya mengambil uang hasil eksekusinya hingga terlunasi tagihan piutangnya, dan jika terdapat sisa uangnya barulah itu menjadi bagian pihak kreditor konkuren. Inilah preferensi kreditor pemegang hipotek sebagai kreditor preferen dalam hal pelunasan hutang yang dilindungi oleh pasal-pasal yang telah dijelaskan di atas dan sesuai asas prioritas dan prinsip Droit de Preference. Sesuai dengan konteks dalam BW, yaitu tidak pari passu atau tidak pula bersama-sama, namun didahulukan, dan tidak prorata atau dibayar keseluruhan hutangnya.

Preferensi kreditor hipotek ini menemui kendala pada saat dilakukan pelelangan atau penjualan obyek jaminan, bilamana obyek jaminan tersebut dijual, lalu hasil penjualan itu telah diserahkan kepada kreditor privilege, dan kemudian dana tidak mencukupi untuk melunasi semua hutang pada kreditor hipotek disaat kreditor hipotek akan menerima pembayaran sebagai pelunasan hutang. Maka seyogyanya karena obyek jaminan itu sudah tidak ada, perjanjian accessoire pun sudah tidak ada lagi, maka dari itu sudah sewajarnya pengaturan beralih kepada Pasal 1131 BW (kreditor hipotek kini menjadi kreditor konkuren). Namun karena hipotek adalah sebagai pelunasan hutang, maka hal ini diatur di dalam Pasal 1176 BW yang menjelaskan bahwa:

Suatu hipotek hanyalah sah, sekedar jumlah uang untuk mana ia telah diberikan, adalah tentu dan juga ditetapkan di dalam akta. Jika utangnya bersyarat atau pun jumlahnya tidak tertentu, maka pemberian hipotek senantiasa adalah sah sampai jumlah harga taksiran, yang para pihak diwajibkan menerangkan di dalam aktanya. 
Dengan adanya pengaturan ini, maka jelas sudah meskipun hutangnya terjamin dengan adanya Pasal 1131 BW, tidak serta-merta membuat seorang kreditor hipotek menjadi kreditor konkuren, namun akan tetap didahulukan sepanjang nilai hutang belum terpenuhi semua.

\section{Privilege dalam Undang-Undang Pelayaran}

Eksisnya kreditor preferen yang mana terlahir dari adanya perjanjian accessoire dimana kedudukannya jelas lebih tinggi daripada kreditor konkuren (yang mana adalah pari passu dan prorata), dari perikatan juga dapat timbul hak yang bersifat serupa, yaitu hak istimewa, yang mana disebut juga hak privilege. Di dalam substansi hukum jaminan, di antara hak-hak yang mana mempunyai keunggulan, diantaranya juga terdapat hak privilege, hak ini juga dinamakan sebagai hak istimewa, hak privilege ini berdasar pada Pasal 1139 dan 1149 BW, dimana terdapat dua macam dari hak ini, yaitu: Privilege Khusus (Pasal 1139 BW). Hak didahulukan terhadap benda tertentu milik debitor (9 macam); Privilege Umum (Pasal 1149 BW). Hak didahulukan terhadap semua harta benda milik debitor (7 macam).

Seperti halnya hak kebendaan, hak privilege ini merupakan hak yang memberikan jaminan untuk didahulukan atau preference, meski mempunyai sifat yang mirip dengan hak kebendaan, namun bukanlah merupakan hak kebendaan, dan bukanlah hal yang tidak mungkin untuk adanya benturan dengan hak kebendaan atau hak lainnya. Pengaturan privilege ini juga tertuang dalam Pasal 316 jo 318 KUHD. Kreditor privilege ini juga dapat mendapatkan preferensinya bila diminta, hal ini berdasar pada Pasal 1209 BW, yaitu terjadi pada saat berakhirnya hipotek. Yang dimaksud dengan privilege ini diterangkan dalam Pasal 1134 BW yaitu suatu kedudukan istimewa dari seorang penagih yang diberikan oleh Undang-Undang berdasarkan sifat piutangnya. Diutarakan oleh Herlin Budiono bahwa hak istimewa atau privilege adalah hak yang mana oleh undang-undang diberikan kepada seorang berpiutang sehingga tingkatannya lebih tinggi daripada orang berpiutang lainnya, untuk dari hasil eksekusi mendapatkan pembayaran yang didahulukan, semata-mata berdasarkan sifat piutangnya (Herlin Budiono, 2008:108).

Ditambahkan oleh Subekti dalam bukunya bahwa piutang-piutang semacam ini dinamakan bevoorrechte schulden. Meskipun privilege ini mempunyai sifatsifat yang menyerupai pand atau hipotek, tetapi kita belum dapat menamakannya suatu hak kebendaan, karena privilege ini barulah timbul apabila suatu kekayaan yang telah disita ternyata tidaklah cukup untuk melunasi semua hutang dan arena privilege itu tidak memberikan suatu kekuasaan terhadap suatu benda. Seorang penagih yang mempunyai privilege pun tidak dapat menyita suatu benda jika ia tidak mempunyai title eksekutorial, misalnya suatu putusan hakim (Subekti, 2003:88).

Menurut Pasal 1138 BW, ada 2 (dua) macam privilege, yaitu Privilege Khusus (Pasal 1139 BW), dan Privilege Umum (Pasal 1149 BW), menurut Pasal 1139 BW, privilege khusus ada 9 (sembilan macam) yaitu piutang-piutang yang diistimewakan terhadap benda-benda tertentu yaitu: 1. Biaya perkara yang semata-mata disebabkan suatu penghukuman untuk melelang suatu benda bergerak maupun tidak bergerak. Biaya ini dibayar dari pendapatan penjualan benda tersebut terlebih dahulu dari semua piutangpiutang lainnya yang diistimewakan, bahkan lebih dulu dari gadai dan hipotek; 2. Uang-uang sewa dari benda-benda tak bergerak, biaya-biaya perbaikan yang menjadi wajibnya si penyewa, beserta segala apa yang mengenai kewajiban persetujuan sewa; 3 . Harga pembelian akan benda-benda bergerak yang mana belum dibayar; 4. Biaya yang telah dikeluarkan untuk menyelamatkan suatu barang; 5. Biaya untuk melakukan suatu pekerjaan pada suatu barang, yang mana masih harus dibayar kepada seorang tukang; 6 . Apa yang telah diserahkan oleh seorang pengusaha rumah penginapan sebagai demikian kepada seorang tamu; 7. Upah-upah pengangkutan dan biaya-biaya tambahan; 8. Apa yang harus dibayar kepada tukangtukang batu, tukang-tukang kayu dan lain-lain tukang pembangunan, penambahan dan perbaikan-perbaikan benda tak bergerak, asal saja piutangnya tidak lebih tua dari tiga tahun dan hak milik atas persil yang bersangkutan masih tetap ada pada si berutang; 9 . Penggantian dan juga pembayaran yang mana dipikul oleh pegawai yang memangku jabatan umum karena kelalaian, kesalahan, pelanggaran, dan kejahatan yang dilakukan dalam melaksanakan tugasnya.

Dari rumusan yang diberikan dalam Pasal 1139 BW ini dapat diketahui adanya 9 (sembilan) jenis piutang yang harus didahulukan pelunasannya atau pembayarannya atas penjualan kebendaan tertentu. Dan yang kedua disebut Privilege Umum (Pasal 1149 BW) yang juga menjabarkan adanya 7 (tujuh) macam dari privilege umum, yaitu piutang-piutang yang diistimewakan atas semua benda bergerak dan tak bergerak pada umumnya ialah yang disebutkan di bawah ini piutang-piutang mana yang dilunasi dari pendapatan penjualan benda-benda itu menurut urutan sebagai berikut: Biaya perkara; Biaya penguburan; 
Biaya pengobatan yang terakhir dari seorang debitor yang telah meninggal dunia (biaya ini meliputi biaya dokter, pembelian obat dan perawatan rumah sakit); Tagihan buruh atas upahnya untuk satu tahun dalam tahun kerja yang sedang berjalan; Uang pembelian barang-barang makanan untuk keperluan hidup seharihari yang diperlukan oleh si berutang dan keluarganya; Tagihan sekolah asrama untuk satu tahun terakhir; Piutang seorang yang belum dewasa atau seorang yang berada di bawah pengampuan terhadap seorang wali atau curator.

Perbedaannya, privilege dalam Pasal 1139 BW, tidak menentukan urutannya, namun dalam Pasal 1149 BW ditentukan urutannya, yang lebih dahulu disebut itu yang didahulukan pembayarannya (Djaja S. Meliala, 2007:24). Dan privilege umum lebih mempunyai arti akan hak tagihan yang diistimewakan dalam mengambil perlunasan atas hasil penjualan dalam suatu eksekusi atas semua benda milik debitor, sedangkan privilege khusus adalah piutang-piutang yang diistimewakan terhadap benda-benda tertentu (Djaja S. Meliala, 2007:24).

Menilik dari pendapat Subekti di atas, maka seperti halnya hak kebendaan, hak privilege ini merupakan hak yang memberikan jaminan untuk didahulukan atau preference, meski mempunyai sifat yang mirip dengan hak kebendaan, namun bukanlah merupakan hak kebendaan, dan bukanlah hal yang tidak mungkin untuk adanya benturan dengan hak kebendaan atau hak lainnya. Pengaturan privilege ini juga tertuang dalam Pasal 316 jo 318 KUHD.

Berdasar pengaturan BW di atas maka ada 2 (dua) macam preferensi, yaitu Droit de Preference pada hak kebendaan (gadai dan hipotek), dan hak mendahulu pada hak istimewa atau privilege. Sedangkan diluar BW lembaga jaminan yang dapat melahirkan Droit de Preference pada kreditornya adalah Hak Tanggungan dan Fiducia, sesuai undang-undang yang mengatur masing-masing antara lain adalan Undang-Undang Jaminan Fiducia (selanjutnya disebut UUJF) dan juga Undang-Undang Hak Tanggungan (selanjutnya disebut UUHT). Pada pengaturan BW, khususnya dalam Pasal 1139 dan 1149 BW, dapat diketahui dari kata biaya ini lebih didahulukan daripada gadai dan hipotek, yang kemudian dapat diasumsikan bahwa pemegang hak privilege ini sebenarnya lebih tinggi daripada pemegang hak kebendaan terutama hipotek, sebagaimana dikemukakan oleh Agus Yudha Hernoko bahwa sesunggunya hak privilege diberikan sematamata berdasarkan sifat piutangnya sesuai aturan dalam BW, dan merupakan hak yang memberikan jaminan untuk didahulukan, sebagai droit de preference dalam
Pasal 1133 BW, dan sebenarnya hak kebendaan lebih tinggi daripadanya, kecuali UU menentukan lain, seperti pada Pasal 1134 ayat 2 BW (Agus Yudha Hernoko, 2007:10).

Pengaturan sebagaimana dalam Pasal 1133 BW, 1134 BW, 1139 BW dan 1149 BW, telah mengatur bahwa preferensi kreditor hipotek sebagai pemegang hak kebendaan ini tidak begitu kuatnya dalam hal pelunasan hutang, bahkan seorang kreditor pemegang hipotek dapat kehilangan preferensinya bilamana undang-undang menentukannya, yaitu saat bertemu atau berbenturan dengan kreditor privilege.

Memahami apa yang dijelaskan di dalam Pasal 1134 ayat $2 \mathrm{BW}$, bahwa ada suatu pengecualian (dari kata sepanjang undang-undang menentukan lain), pengecualian ini ditentukan oleh undang-undang dalam hal berikut ini (J. Satrio III, xxx:32): Pasal 1139 dan Pasal 1149 BW; Pasal 1142 BW, dalam hal dengan syarat-syarat tertentu, hak orang yang menyewakan ditaruh di atas pemegang gadai; Pasal $1150 \mathrm{BW}$, dalam hal biaya-biaya untuk menyelamatkan barang yang telah digadaikan atas di atas gadai; Pasal 316 jo 318 KUHD, hak tagihan atas kapal; Pasal 1137 BW yang mengatur tentang privilege tentang fiskal.

Bertalian dengan hal pelayaran, yaitu kapal, selain dalam BW, diatur juga dalam Pasal 316 jo 318 KUHD seperti yang telah disebutkan di atas. Pasal 316 KUHD menentukan secara khusus tentang hak privilege, dan dalam pasal 316a KUHD ditentukan berdasarkan ranking atau urutan akan hutang yang diistimewakan, yaitu: Biaya-biaya lelang sita (eksekusi); Piutang yang terbit dari perjanjian perburuhan, dari nahkoda, dari anak buah kapal; Upah penolongan, upah pandu laut, uang petunjuk dan uang pelabuhan dan lain-lain biaya pelayaran; Piutang karena penubrukan. Pasal 1139 BW tidak berlaku terhadap kapal.

Disini jelas ditegaskan bahwa Pasal 1139 BW kini sudah tidak lagi berlaku dalam hal privilege pelayaran. Dapat ditarik suatu pengertian dari uraian di atas bahwa Pasal 1139 yang menyebutkan secara khusus hak-hak privilege itu sudah tidak diberlakukan oleh Pasal 316 KUHD, karena Pasal 316 KUHD telah menyebutkan secara rinci dan khusus akan privilege dalam hal pelayaran. Disamping pengaturan privilege pelayaran ada dalam KUHD, dalam UU Pelayaran juga terdapat pengaturan mengenai privilege, hal ini sebagaimana yang diatur dalam Pasal 1 angka 13, piutang-pelayaran yang didahulukan adalah tagihan yang wajib dilunasi lebih dahulu dari hasil eksekusi kapal mendahului tagihan pemegang hipotek kapal.

Pasal 65 UU Pelayaran sebagai berikut: Pertama, Apabila terdapat suatu gugatan terhadap piutang 
yang dijamin dengan kapal, pemilik, pencarter, atau operator kapal harus mendahulukan pembayaran piutang-pelayaran yang didahulukan; Kedua, Piutangpelayaran yang didahulukan sebagaimana dimaksud pada ayat 1 yaitu sebagai berikut: untuk pembayaran upah dan pembayaran lainnya kepada Nakhoda, Anak Buah Kapal, dan awak pelengkap lainnya dari kapal dalam hubungan dengan penugasan mereka di kapal, termasuk biaya repatriasi dan kontribusi asuransi sosial yang harus dibiayai; untuk membayar uang duka atas kematian atau membayar biaya pengobatan atas adanya luka-luka badan, baik yang terjadi di darat maupun di laut yang berhubungan langsung dengan pengoperasian kapal; untuk pembayaran biaya salvage atas kapal; untuk biaya pelabuhan dan alur-pelayaran lainnya serta biaya pemanduan; dan untuk membayar kerugian yang ditimbulkan oleh kerugian fisik atau kerusakan yang mana disebabkan oleh pengoperasian kapal selain dari kerugian atau kerusakan terhadap muatan, peti kemas, dan barang bawaan penumpang yang diangkut di kapal. Ketiga, Piutang-pelayaran yang didahulukan tidak dapat dibebankan atas kapal untuk menjamin gugatan sebagaimana dimaksud pada ayat 2 huruf $b$ dan huruf e apabila tindakan tersebut timbul sebagai akibat dari: kerusakan yang timbul dari angkutan minyak atau bahan berbahaya dan beracun lainnya melalui laut; dan bahan radioaktif atau kombinasi antara bahan radioaktif dengan bahan beracun, eksplosif atau bahan berbahaya dari bahan bakar nuklir, produk, atau sampah radioaktif.

Dan dalam Pasal 66 UU Pelayaran dijelaskan lebih lanjut: Pertama, Pembayaran piutang-pelayaran yang didahulukan sebagaimana dimaksud dalam Pasal 65 diutamakan dari pembayaran piutang gadai, hipotek, dan piutang-piutang yang terdaftar. Kedua, Pemilik, pencarter, pengelola, atau juga operator kapal harus mendahulukan pembayaran terhadap biaya yang akan timbul selain dari pembayaran piutang-pelayaran yang didahulukan sebagaimana dimaksud dalam Pasal 65. Ketiga, Biaya sebagaimana dimaksud pada ayat 2 berupa: biaya yang timbul dari pengangkatan kapal yang tenggelam atau terdampar yang dilakukan oleh pemerintah untuk menjamin keselamatan pelayaran atau perlindungan lingkungan maritim; dan biaya perbaikan kapal yang menjadi hak galangan atau dok (hak retensi) jika pada saat penjualan paksa kapal sedang berada di galangan atau dok yang berada di wilayah hukum Indonesia. Keempat, Piutangpelayaran sebagaimana ditetapkan dalam Pasal 65 mempunyai jenjang prioritas sesuai dengan urutannya, kecuali apabila klaim biaya salvage kapal telah timbul terlebih dahulu mendahului klaim yang lain, biaya salvage menjadi prioritas yang lebih dari piutangpelayaran yang didahulukan lainnya.

Dari penjabaran atas pasal-pasal yang mengatur tentang pelayaran di atas, dapat dipahami bahwa Pasal 1 angka 13 UU Pelayaran menegaskan bila privilege harus didahulukan, dan Pasal 66 ayat $1 \mathrm{UU}$ Pelayaran menegaskan lagi bila pembayaran piutang pelayaran yang didahulukan sebagaimana dimaksud Pasal 65 UU Pelayaran diutamakan dari pembayaran piutang hipotek, dan piutang-piutang yang terdaftar. Dan lebih lagi dalam Pasal 66 ayat 2 UU Pelayaran menyebutkan bahwa pemilik, pencarter, pengelola, atau operator kapal harus mendahulukan pembayaran terhadap biaya yang timbul selain dari pembayaran piutang yang didahulukan sebagaimana dimaksud dalam Pasal 65 UU Pelayaran. Ini berarti ada yang harus didahulukan daripada yang didahulukan dalam Pasal 65 ayat 2 UU Pelayaran, yaitu yang disebutkan dalam Pasal 66 ayat 3 UU Pelayaran. Juga dalam Pasal 66 ayat 4 UU Pelayaran diatur sejalan dengan Pasal 318 KUHD yang mana pembayaran yang didahulukan adalah mengenai salvage kapal, ganti rugi karena rusak atau musnahnya kapal maupun dari piutang yang disebutkan dalam pasal 316c KUHD.

Dalam hal pelayaran khususnya pada pengaturan dalam UU Pelayaran, ada hak privilege yang tidak dapat ditagih, meskipun tergolong hak privilege, hal ini disebutkan di dalam Pasal 65 ayat 3 yaitu piutang-pelayaran yang akan didahulukan itu tidak dapat dibebankan atas kapal untuk menjamin gugatan sebagaimana dimaksud pada ayat 2 huruf $b$ dan huruf e apabila tindakan tersebut timbul sebagai akibat dari: kerusakan yang timbul dari angkutan minyak atau bahan berbahaya dan beracun lainnya melalui laut; dan bahan radioaktif atau kombinasi antara bahan radioaktif dengan bahan beracun, eksplosif atau juga bahan berbahaya dari bahan bakar nuklir, produk, atau sampah radioaktif. Jadi dapat diketahui bahwa meskipun tergolong hak privilege dalam hal sebagaimana disebutkan dalam Pasal 65 ayat 2 UU Pelayaran dalam huruf $b$ dan huruf e yaitu tidak dapat ditagih jika terpenuhi unsur dalam Pasal 65 ayat 3 UU Pelayaran.

Dapat dipahami dari uraian di atas, bahwa hak privilege ini lahir dan menang atas kreditor hipotek dengan alur sesuai asas Lex Specialis Derogat Legi Generalis adalah: Aturan Pasal 1134 BW (Gadai dan Hipotek didahulukan dari hak istimewa, kecuali undang-undang mengatur lain); Aturan Pasal 1139 dan 1149 BW (beberapa bentuk pengecualian akan didahulukannya hipotek); Aturan Pasal 316 jo 318 KUHD (pengaturan akan hak yang mendahului dari 
preferensi kreditor hipotek); Aturan Pasal 1 angka 13, Pasal 65, dan Pasal 66 UU Pelayaran (ternyata UU Pelayaran mengatur juga mengenai hak privilege).

Seperti yang telah dijelaskan di atas, privilege ini hanya semata-mata kuat karena sifat piutangnya, kreditor privilege tidak bisa menjual sendiri obyek jaminan hipotek, namun kreditor hipotek bisa karena dalam akta hipotek terdapat kuasa menjual sendiri benda jaminannya atau beding van eigenmachting verkoop (sebagaimana telah dijelaskan dalam bab sebelumnya), yang diatur dalam Pasal 1178 ayat (2) $\mathrm{BW}$, dan dengan kuasa menjual, kreditor hipotek tidak perlu mendapat persetujuan dari debitor dan tidak perlu meminta penetapan pengadilan apabila akan melakukan suatu eksekusi atas benda jaminan. Kreditor pemegang hipotek dapat langsung datang dan mengajukan permohonan lelang kepada kantor lelang untuk melakukan pelelangan. Kuasa menjual ini merupakan suatu kuasa mutlak (onherroepelijk) artinya bahwa kuasa tersebut tidaklah dapat ditarik kembali dan harus dicantumkan dalam akta hipotek (Djuaendah Hasan, 1996:324). Dan dengan adanya kuasa menjual, maka kreditor pemegang hipotek mempunyai keuntungan dua hal, yaitu: Pertama, Tidak membutuhkan suatu title eksekutorial dalam melaksanakan eksekusi (melainkan dengan parate eksekusi). Berdasarkan Pasal 1211 BW, pelaksanaan eksekusi atas kuasa menjual haruslah memenuhi ketentuan sebagai berikut: Penjualan harus dilakukan di muka umum; Berdasarkan kebiasaan setempat, penjualan harus dilakukan dihadapan pegawai umum yaitu pegawai kantor lelang Negara. Kedua, Dapat melaksanakan eksekusi sendiri secara langsung atau mandiri, tak peduli adanya kepailitan dari debitor (di luar kepailitan) karena dia tergolong separatis (Djuaendah Hasan, 1996:324).

Bertalian dengan adanya proses eksekusi jaminan di atas, berdasarkan pada undang-undang pemegang jaminan kebendaan dapat memilih beberapa alternatif pelunasan piutangnya melalui beberapa hal, antara lain:

Pertama, Dengan cara melakukan penjualan obyek jaminan atas kuasanya sendiri atau yang kemudian disebut istilah parate eksekusi bagi pemegang jaminan pertama. Parate eksekusi ini dapat diterapkan di Gadai (1151 BW), Hipotek (1178 ayat 2 BW), Hak Tanggungan (Pasal 6 UUHT), Fidusia (Pasal 15 ayat 3 UUJF).

Kedua, Dengan menggunakan title eksekutorial melalui fiat ketua Pengadilan Negeri dengan cara menggunakan ketentuan Pasal 224 HIR/258 Rbg tentang eksekusi grosse akta: 1. Titel eksekutorial berbunyi "DEMI KETUHANAN YANG MAHA ESA", yang mana merupakan suatu simbol bahwa suatu dokumen atau naskah itu memiliki kekuatan eksekusi dengan bantuan dari alat Negara. Dokumen tersebut dapat berupa putusan pengadilan, grosse akta hipotek, sertifikat hak tanggungan, sertifikat fidusia, maupun grosse akta pengakuan utang. Atas adanya titel eksekutorial ini, pemegangnya dapat mengajukan suatu permohonan pelaksanaan eksekusi secara paksa kepada pengadilan, dan pengadilan akan melaksanakannya melalui prosedur eksekutorial (J. Satrio, 1993:5); 2. Syarat-syarat formal yang harus dipenuhi agar suatu grosse akta mempunyai kekuatan eksekutorial yaitu: a. Harus berkepala Demi Keadilan Berdasarkan Ketuhanan Yang Maha Esa; b. Di bawah harus dicantumkan kata-kata Diberikan sebagai grosse akta hipotek pertama; c. Dicantumkan pula nama orang yang mana atas permintaannya grosse akta ini diberikan; d. Dicantumkan pula tanggal pemberian grosse akta tersebut, dan berkedudukan dimana orang yang mana atas permintaannya grosse akta tersebut diberikan (Hartono Soerjopratiknjo, 2009:94-95); 3. Parate eksekusi tidak membutuhkan dan tidak berjalan atas dasar title eksekutorial, namun karena kuasanya, dan sebagai contoh sederhana, mengenai gadai, meskipun pada jaminan gadai tanpa adanya titel eksekutorial, namun pemegang jaminan tetap dapat melakukan parate eksekusi jika batas waktu penebusan telah usai (J. Satrio, 1993:5).

Ketiga, Dengan cara penjualan di bawah tangan berdasarkan kesepakatan kedua belah pihak untuk mendapat harga penjualan yang lebih tinggi.

Dari sini dapat diketahui bahwa kreditor hipotek sebagai kreditor preferen pemegang hak kebendaan sebenarnya kedudukannya juga lebih tinggi daripada kreditor privilege, hanya saja dalam hal uang yang didapat, kreditor privilege ini akan lebih mendahului. Kelemahan dari kreditor privilege adalah tiadanya kuasa untuk menjual bahkan menyita suatu benda (Subekti, 2003:88).

Kelemahan lain dari kreditor privilege ini, yaitu privilege ini lahir bilamana diminta, dengan kata lain, bilamana dalam suatu pelunasan hutang, kreditor yang mana sebenarnya bisa menjadi kreditor privilege ini tidaklah mengajukan dirinya sebagai kreditor yang mana harus didahulukan untuk pembayarannya, maka kreditor tersebut menjadi kreditor konkuren, hal ini sebagaimana dikatakan J. Satrio dalam bukunya, privilege harus dituntut, harus dimajukan, artinya: kalau pemilik tagihan yang diistimewakan tinggal diam saja, maka tagihannya dianggap sebagai tagihan biasa atau konkuren. Pemilik tagihan tersebut harus 
menuntut agar dia dimasukkan dalam daftar tingkatan (dalam rangregeling) menurut tingkat yang diberikan kepadanya menurut undang-undang dan juga dengan demikian mendapat perlunasannya menurut urutan tingkatan dalam daftar (J. Satrio, 2005:29).

Selain itu, dalam hal kreditor privilege itu hanya berdasarkan sifat piutangnya saja, kreditor privilege ini tidak mempunyai Droit de Suite yang mana jelas tidak mengikuti bendanya, yang mana berarti apabila barangnya telah dialihkan kepada pihak ketiga, maka hak privilege penjual menjadi hapus. Tidak demikian untuk privilege yang berkaitan dengan kapal, hak privilege yang berlaku pada kapal mempunyai Droid de Suite yang tidak dimiliki hak privilege lain. Hal ini sebagaimana dijelaskan dalam Pasal 316e KUHD, yaitu si berpiutang yang piutangnya diistimewakan, melaksanakan haknya atas kapal atau andil dalam kapal, dalam tangannya siapa pun kapal atau andil itu berada, dan atas penagihan-penagihan yang tersebut dalam Pasal 316c dan 316d juga setelahnya piutangpiutang itu dipindahkan atau digadaikan kepada pihak lain, yaitu pihak ketiga.

Berkaitan dengan ada ketentuan di atas, Mariam Darus Badrulzaman mengungkapkan bahwa hak-hak kreditor yang terbit dari hak yang diistimewakan itu mempunyai kedudukan yang sangat kuat atau Droit de Suite, dalam arti kreditor dapat melaksanakan hak nya atas kapal atau andil dalam kapal, dalam tangan siapapun kapal atau andil itu berada (Mariam Darus Badzrulzaman, 1999:106).

Untuk hal Pasal 316e KUHD ini, Rachmadi Usman juga berpendapat bahwa diantara hak privilege ini juga dalam Buku Kedua BW sejajar dengan hak-hak kebendaan, satu dua hal mempunyai sifat kebendaan juga, dalam satu dua hal menunjukan sifat Droit de Suite (Rachmadi Usman, 2008:520).

Dari sini dapat dipahami bahwa memang seperti yang telah diungkapkan J. Satrio bahwa privilege tidak mempunyai Droit de Suite, namun tidak dapat diterapkan untuk semua jenis hak privilege, karena hak privilege dalam pelayaran mempunyai Droit de Suite. Juga seperti penjelasan di atas dalam pengaturan UU Pelayaran, hak privilege yang mempunyai sifat begitu mendahului pun ada yang tidak dapat ditagih bila memenuhi unsur-unsur tertentu.

\section{Force Majeure}

Peristiwa tak terduga atau force majeure adalah keadaan dimana seorang debitor terhalang untuk melaksanakan prestasinya karena ada suatu keadaan atau peristiwa yang tidak terduga pada saat dibuatnya kontrak, keadaan atau peristiwa tersebut tidak dapat dipertanggungjawabkan kepada debitor, sementara si debitor tersebut tidak dalam keadaan beriktikad buruk, dan acapkali peristiwa yang mana merupakan force majeure tersebut tidak termasuk dalam asumsi dasar atau basic assumption para pihak yang terlibat dalam perjanjian. Hal ini sungguh merupakan suatu penghalang untuk terciptanya suatu hubungan baik kreditor dan debitor, dan tentunya juga berimbas pada pemenuhan prestasi pada perjanjian hipotek yang bersangkutan.

Keadaan memaksa secara fragmentis tertuang dalam BW, namun demikian BW tidak merumuskan batasan akan keadaan memaksa ini, Suryodiningrat memberian batasan sebagai berikut Keadaan memaksa ialah peristiwa yang terjadi di luar kesalahan debitor setelah dibuat perikatan yang debitor tidak dapat memperhitungkannya terlebih dahulu pada waktu dibuatnya perikatan, atau sepatut-patutnya tidaklah dapat memperhitungkannya, dan yang merintangi pelaksanaan perikatan.

Serupa dengan pendapat Agus Yudha Hernoko yang memberikan batasan sebagai berikut, dapat disimpulkan bahwa merupakan peristiwa yang tidak terduga yang terjadi diluar kesalahan debitor setelah penutupan kontrak yang menghalangi debitor untuk memenuhi prestasinya, sebelum ia dinyatakan lalai dan karenanya tidak dapat dipersalahkan serta tidak menanggung resiko atas kejadian tersebut (Agus Yudha Hernoko, 2010:270-271)

Mengenai pengaturan dalam BW, Agus Yudha Hernoko juga menjabarkannya dengan lebih detail dalam bukunya, terkait dengan overmacht, Buku III BW mengaturnya secara fragmentis atau tersebar dalam beberapa pasal, yaitu pada bagian IV tentang Penggantian Biaya, Rugi dan Bunga karena tidak dipenuhinya akan suatu perikatan (Pasal 1244-1245 BW) dan Bagian VII tentang Musnahnya Barang yang Terutang (Pasal 1244-1445 BW) (Agus Yudha Hernoko, 2010:270).

Dalam hal pendalilan force majeure, overmacht, Yohanes Sogar Simamora mengemukakan dalam bukunya, dalam perspektif Hukum Perikatan, dalil keadaan memaksa yang diajukan oleh debitor terkait dengan tidak dipenuhinya suatu perikatan. Oleh sebab itu klausula keadaan memaksa hanya relevan untuk executory contract dan tidak untuk executed contract (Y. Sogar Simamora, 2010:338)

Kedua hal ini saling berkaitan dengan pemenuhan prestasinya, keberlakuan keadaan memaksa ini tidak berlaku dalam perikatan yang mana pemenuhannya dengan bentuk prestasi tidak berbuat sesuatu, dan pada karakteristiknya, keadaan memaksa itu menghapus 
perbuatan wanprestasi pada debitor. J. H. Niuwenheis yang dalam bukunya hasil terjemahan D. Saragih juga mengemukakan bilamana terdapat dua unsur yang harus dipenuhi oleh debitor dalam menggunakan dalil keadaan memaksa ketika ia tidak dapat memenuhi kewajibannya, yakni: pertama, pemenuhan prestasi harus tercegah, dalam artian debitor secara patut memang tidak mampu untuk mencegah terjadinya peristiwa yang menghalangi perikatan itu, dan kedua, pencegahan itu tidak dapat dipertanggungjawabkan kepada debitor, dalam hal ini debitor harus bertindak selaku kepala keluarga yang baik dan telah menjaga terhadap kemungkinan pencegahan prestasi yang terutang (J.H. Nieuwenhuis, 1985:91-92)

Memang benar bilamana dicermati, tidak terdapat suatu pasal pun yang mengatur force majeure secara umum untuk suatu kontrak bilateral (prestasinya timbal balik), yang dapat kita lakukan adalah menarik kesimpulan-kesimpulan umum daripada pengaturanpengaturan khusus, yaitu pengaturan khusus tentang force majeure yang terdapat dalam bagian pengaturan tentang ganti rugi, atau pengaturan resiko akibat force majeure untuk kontrak sepihak atau pun dalam bagian kontrak-kontrak khusus (kontrak bernama). Di samping tentunya juga menarik kesimpulan dari teori-teori hukum tentang force majeure, doktrin dan yurisprudensi.

Pasal 1209 BW mengatur bahwa hapusnya hipotek disebabkan karena: hapusnya perikatan pokoknya; pelepasan hipotek oleh si berpiutang; dan karena penetapan hakim.

Dari penjabaran pada pasal ini, berarti bahwa musnahnya kapal yang menjadi obyek hipotek tidak termasuk dalam hal yang menyebabkan hapusnya hipotek, tidak seperti lembaga jaminan fidusia yang mengatur dengan jelas bahwa bila obyek jaminan musnah maka fidusia akan ikut berakhir (UndangUndang No. 42 Tahun 1999 tentang Jaminan Fidusia, selanjutnya disebut UUJF). Namun pada dasarnya hipotek adalah perjanjian accesoire, bila obyek yang ada dalam perjanian accessoire itu musnah, maka sudah seyogyanya perjanjiannya juga hapus dengan sendirinya, dan tertinggal perjanjian induknya saja. Sebenarnya dengan menilik pada uraian di atas itu, kreditor preferen hipotek kini sudah menjadi kreditor konkuren, namun bila diteliti lebih lanjut sebenarnya hal ini (musnahnya obyek jaminan hipotek) tidak serta merta membuat kreditor dalam perjanjian accessoire menjadi kreditor konkuren .

Hal ini sejalan dengan penjelasan di atas bahwa kreditor hipotek tetap didahulukan sepanjang nilai hipotek belum terpenuhi, yaitu berdasar pada Pasal
1176 BW. Sebagaimana telah dijelaskan sebelumnya, bahwa adanya janji-janji yang tertuang dalam SKMH berimplikasi pada pihak ketiga. Janji-janji inilah yang melahirkan sifat preferensi kreditor hipotek dalam pelunasan hutang, walaupun sebenarnya telah menjadi kreditor konkuren karena obyeknya musnah. Dengan adanya janji-janji tersebut, kreditor hipotek tetap mendapatkan pelunasannya terlebih dahulu, namun tentu saja tidak lebih dahulu dari kreditor privilege bila ada pengajuan darinya.

Dalam perjanjian induknya tersebut juga pasti sudah dijelaskan siapa para pihak dalam perjanjian dan juga bentuk jaminannya, serta adanya lampiran akan daftar-daftar register benda yang dijaminkan, yang mana semata-mata untuk perlindungan kreditor. Maka karena tidak ada pengaturan yang cukup jelas mengenai akibat hukum dari musnahnya kapal laut yang menjadi obyek hipotek, hal tersebut tentunya dikembalikan pada kesepakatan antara debitor dengan kreditor pada perjanjian hipotek (sebagai perjanjian accessoire) atau perjanjian kredit (sebagai perjanjian pokok hutang piutang).

\section{Kreditor Pemegang Hak Hipotek Sebagai Pihak Penerima Santunan Asuransi}

Asuransi yang memang ditujukan untuk kapal laut, biasanya mencakup 2 hal, yang pertama adalah General Average, dan yang kedua adalah Particular Average, mengenai kedua hal tersebut Imam Musjab mengemukakan, kedua hal ini berbeda lingkupnya, General Average ditujukan untuk melindungi dari tabrakan, karam, kandas, dan kejadian ekstrim yang lain, sedangkan Particular Average lebih ditujukan untuk kejadian yang dapat diklasifikasikan sebagai kejadian ringan, contohnya yaitu pencurian loadingunloading risk, dan accidental damage lainnya (Imam Musjab, http://ahliasuransi.com/asuransi-kapal-danpi-marine-hull-and-pi/ (diakses tgl.30/10/2012).

Jadi, bila digabungkan, asuransi kapal laut antara lain melindungi atas: bahaya laut seperti cuaca buruk, tenggelam, tabrakan atau perils of the seas; kebakaran, ledakan; pencurian dengan kekerasan; pembuangan kargo ke laut atau jettison; perompakan atau piracy; tabrakan dengan pesawat udara; gempa bumi, letusan gunung berapi, sambaran petir; kelalaian nahkoda dan crew; pemberontakan ataupun pengambilalihan paksa oleh nahkoda dan crew; tanggungjawab hukum akibat tabrakan kapal atau juga Collission Liability; kontribusi General Average and Salvage; biaya-biaya penyelamatan (Imam Musjab, http://ahliasuransi.com/ asuransi-kapal-dan-pi-marine-hull-and-pi/ (diakses $\operatorname{tgl} 1.30 / 10 / 2012)$. 
Hal ini setara dengan yang disebutkan juga dalam Undang-Undang Pelayaran, bahwasanya hal-hal yang membutuhkan asuransi, antara lain: Jaminan akan diangkatnya bangkai kapal (Pasal 203); Jaminan akan dibayarnya bila ada pencemaran (Pasal 231); Jaminan akan perlindungan crew (Pasal 151).

Asuransi hipotek ini, diatur juga dalam pasal 297 KUHD, dan klausula pengasuransian ini kerapkali dicantumkan dalam bentuk janji-janji dalam Surat Kuasa Memasang Hipotek, yang mana nantinya akan diwujudkan dalam perjanjian jaminan hipotek.

Dalam janji asuransi atau Assurantie Beding berisi mengenai kreditor yang akan menerima uang hasil pembayaran klaim asuransi, namun kenyataannya di dalam polis asuransi tidak ada kewajiban untuk membayarkan klaim langsung kepada pihak kreditor. Maka dari kreditor perlu mencantumkan Banker's Clause. Pengertian Banker's Clause ini adalah suatu klausul yang menyatakan bahwa kreditor sebagai pihak yang mana menerima santunan asuransi dimana terjadi kerugian atas musnahnya benda yang menjadi obyek jaminan yang dipertanggungkan dalam klaim asuransi. Apabila pada waktu debitor melakukan permohonan kredit obyek jaminan tersebut belum diasuransikan, maka bank harus memberitahukan kepada perusahaan asuransi untuk mencantumkan Banker's Clause. Dengan adanya hal ini, kerapkali kreditor memperjanjikan Banker's Clause dengan mana perusahaan asuransi terikat untuk membayarkan santunan asuransi kepada kreditor.

Sedikit dari uraian di atas, kreditor hipotek akan mendapatkan santunan asuransi dari suatu perusahaan asuransi sebagai pelunasan hutang debitor, dan juga kreditor privilege mendapatkan santunan asuransi karena hak-hak privilegenya seperti yang telah diatur di dalam undang-undang. Meskipun obyek hipotik tersebut musnah, tidak berarti para kreditor terutama kreditor preferen kemudian menjadi hilang haknya. Kreditor privilege mendapatkan santunan asuransi atas dasar ketentuan undang-undang, sedangkan kreditor hipotek dapat mendapatkan hak pelunasan hutang dari santunan asuransi atas dasar janji asuransi dalam SKMH, dan pencantuman Banker's Clause, sebagai wujud pelunasan hutang dari perjanjian pokoknya. Mengenai hal ini J. Satrio berpendapat, benda yang diasuransikan adalah milik kreditor, dan karenanya yang berhak mendapatkan ganti rugi adalah kreditor (J. Satrio, 2005:238).

Mengenai hal asuransi ini, Instruksi Presiden No. 5 tahun 2005 tentang Pemberdayaan Industri Pelayaran Nasional telah menginstruksikan kepada menteri yang berwenang untuk melakukan dan merumuskan kebijakan-kebijakan sebagaimana berikut: Pertama, setiap kapal yang dimiliki dan/atau dioperasikan oleh perusahaan pelayaran nasional, dan/atau kapal bekas/ kapal baru yang akan dibeli atau dibangun di dalam atau di luar negeri untuk jenis, ukuran dan batas usia tertentu wajib diasuransikan sekurang-kurangnya yaitu Hull \& Machineries (rangka kapal); Kedua, muatan atau barang dan penumpang yang diangkut oleh perusahaan pelayaran nasional yang beroperasi baik di dalam negeri maupun di luar negeri, wajib diasuransikan; Ketiga, menetapkan kebijakan yang akan mendorong perusahaan asuransi nasional untuk dapat bergerak di bidang asuransi perkapalan untuk menyesuaikan dengan standar kemampuan retensi asuransi perkapalan internasional.

Dengan adanya pengaturan mengenai kewajiban asuransi bagi perkapalan sebagaimana dimaksud di atas, diharapkan hal ini dapat memberikan jaminan kepastian pelunasan utang terhadap kreditor dalam hal terjadi hal yang tidak diharapkan terhadap kapal yang akan dijaminkan tersebut. Atas hal ini Ramlan Ginting mengungkapkan, namun perlu diperhatikan bahwa kewajiban tersebut hanya sekurang-kurangnya atas rangka kapal. Oleh karena itu, kreditor harus melakukan analisis akan apakah nilai pertanggungan asuransi dimaksud mencukupi pembayaran seluruh kewajiban debitor. Pengaturan yang seperti ini akan mengurangi kemungkinan timbulnya kerugian yang lebih besar pada kreditor (Ramlan Ginting, 2008).

Terdapat perbedaan antara santunan asuransi, dan uang hasil dari penjualan obyek jaminan hipotek, dalam rangka mendapatkan uang untuk pemenuhan pembayaran hutang debitor. Persamaannya, keduanya sama-sama merupakan suatu jalan mendapatkan dana yang tidak dengan cara normal melainkan keduanya karena adanya suatu hal yang terjadi. Setelah dana didapatkan, kreditor privilege berhak mendapatkan perlunasannya terlebih dahulu (bila diminta, sesuai penjabaran di atas). Perbedaannya, santunan asuransi dikarenakan adanya musibah pada kapal, sedangkan hasil penjualan obyek jaminan itu berkaitan dengan debitor wanprestasi, perbedaannya adalah mengenai jumlah dari santunan itu sendiri.

Dana hasil penjualan obyek hipotek itu selalu berkaitan dengan pailitnya pihak debitor, atau karena debitor wanprestasi, penjualan ini tidaklah rumit, karena seperti yang telah dijelaskan sebelumnya bahwasanya janji kuasa menjual yang ada dalam akta hipotek sungguh berperan dalam hal ini. Hasil penjualan obyek hipotek ini tidaklah jarang terjadi kelebihan dana yang didapat dari hasil jual, dan bila ini terjadi maka uang tersebut dapat dimiliki oleh debitor 
yang kemudian digunakan untuk membayar kreditor lain, atau keperluan lain setelah hutang terpenuhi. Sebagaimana diungkapkan oleh Gunawan Widjaja bahwa, jika hasil penjualan kebendaan yang diberikan kedudukan istimewa atau sebagai jaminan kebendaan tersebut lebih besar dari piutang kreditor privilege dan atau kreditor pemegang hipotek yang bersangkutan, maka sisa hasil pejualan diserahkan kembali kepada debitor (atau disebut juga sebagai harta pailit dalam hal kepailitan), untuk dapat melunasi piutang kreditor konkuren yang lainnya (Gunawan Widjaja, 2005:10). Bertalian dengan jaminan hipotek adalah sebagai pelunasan hutang, maka bilamana semua hutang telah dilunasi, bila masih ada dana yang berlebih, dana tersebut sudah sewajarnya dapat dimiliki oleh debitor (vide pasal $1162 \mathrm{BW}$ ).

Dana dari santunan asuransi didapatkan melalui proses klaim, tentunya dengan bukti bilamana ada musibah dari suatu kapal yang bersangkutan hingga diperlukan penggantian. Seperti yang telah dijelaskan dalam bab sebelumnya, bahwa adanya tiga prinsip utama asuransi khususnya asuransi pengangkutan laut, yaitu insurable interest, principle of indemnity dan goodfaith, maka dari itu dengan adanya insurable interest sebagai konsekuensinya adalah jaminan atau indemnity (Radiks Purba, 1998:10). Jaminan timbul jika ada kerugian atas insurable interest, sebaliknya jika tidak ada sesuatu yang ditanggung, maka juga tidak ada jaminan karena tidak ada kerugian yang diganti sekalipun ada insurable interest yang legal. Berbeda dengan dana yang didapat dari hasil lelang atau jual, dana dari asuransi ini diatur untuk tidak berlebih. Sebagaimana diungkapkan oleh Radiks Purba bahwasanya

Atas kerugian yang ditanggung oleh penanggung, tertanggung tidak dibolehkan mencari (mendapat) keuntungan. Inilah yang merupakan acuan dasar pertimbangan dari prinsip indemnity. Berpedoman pada prinsip ini, maka tertanggung akan memperoleh ganti rugi dari penanggung untuk mengganti kerugian yang dideritanya dengan tujuan: 1 . mengembalikan tertanggung ke keadaannya semula sebelum kerugian menimpanya; atau 2. menghindarkan tertanggung dari bangkrut sedemikian rupa sehingga dia masih dapat berdiri di tempatnya (Radiks Purba, 1998:12).

Bilamana tertanggung mengalami kerugian atau kerusakan kapal laut seluruhnya, maka tertanggung akan mendapatkan ganti rugi: Pertama, Jika harga pertanggungan yang mana tercantum pada polis sama dengan harga barang yang sebenarnya (real value), maka tertanggung memperoleh ganti rugi sebesar harga barang yang sebenarnya, yaitu sebesar kerugian yang dia derita; Kedua, Jika harga pertanggungan yang tercantum di dalam polis itu lebih besar dari harga barang yang sebenarnya, maka tertanggung memperoleh ganti rugi sebesar harga barang yang sebenarnya, yaitu sebesar kerugian yang dia derita; Ketiga, Bilamana harga pertanggungan yang mana tercantum pada polis itu lebih kecil dari harga barang yang sebenarnya, berarti tidak ditutup pertanggungan untuk semua barang, maka tertanggung memperoleh ganti rugi sebesar harga pertanggungan, yaitu sebesar harga barang yang ditanggung. Sisa kerugian, yaitu sebesar nilai harga barang yang tidak ditutup nilai pertanggungannya, itu nantinya akan menjadi beban (J.E. Kaihatu, 1995:12).

Di dalam buku yang sama, Kaihatu kemudian menambahkan bahwa, prinsip penyelesaian ganti rugi dengan prinsip real value, lebih kecil atau lebih besar merupakan dasar pokok untuk menyelesaikan ganti rugi, jika harga pertanggungan itu ditentukan berdasarkan insured value, yaitu dengan besarnya harga pertanggungan yang mana dicantumkan dalam polis semata-mata didasarkan kepada harga barang sebagaimana yang diberitahukan oleh tertangggung pada waktu menutup suatu pertanggungan asuransi (J.E. Kaihatu, 1995:12).

Sebagaimana pada umumnya, dalam praktek, cara ini sulit untuk diterapkan dikarenakan situasi ekonomi yang tidak stabil pula, pihak yang bertujuan aman dengan asuransi, dapat menjadi rugi bila harga kapal berubah drastis, bahkan jatuh, maka benar-benar akan ditemui kesulitan untuk memperoleh harga barang yang sebenarnya sebagai patokan di dalam polis asuransi. Untuk ini Radiks Purba menyampaikan dalam bukunya, karena adanya suatu kesulitan untuk memperoleh harga barang yang sesungguhnya, maka dalam pertanggungan angkutan muatan laut dikenal dengan adanya polis atas dasar agreed value, yaitu besarnya harga pertanggungan yang dicantumkan pada polis sesuai dengan yang disetujui (agreed) oleh kedua belah pihak. Dalam kondisi agreed value ini maka besarnya ganti rugi untuk total loss (kerusakan seutuhnya) adalah sebesar harga pertanggungan, tanpa mengindahkan harga barang yang sebenarnya (Radiks Purba, 1998:13).

Dari sini dapat dipahami, bahwasanya kreditor pemegang hipotek sebagai kreditor preferen yang berhak atas santunan asuransi, posisinya berbeda bilamana dana datang dari hasil penjualan, dimana santunan asuransi ini tidak menimbulkan kelebihan dana yang dapat dimiliki oleh debitor.

Adanya hak privilege, ternyata diatur juga dalam pengasuransian. Dalam hal perlindungan dan ganti- 
rugi, asuransi P\&I memberikan hal-hal sebagai berikut (Imam Musjab, www.ahliasuransi.com, wawancara via telepon pada tanggal 11/11/2012): Penanggung akan mengganti kerugian tertanggung atas kewajiban, kerugian, biaya dan pengeluaran, yang timbul dari peristiwa yang terjadi selama periode asuransi dan dikeluarkan oleh tertanggung sehubungan dengan pengoperasian kapal yang dipertanggungkan, antara lain: 1. Penyelamatan hidup; 2. Cedera tubuh: tubuh penumpang cedera, crew dan lainnya; 3. Karantina: berhubungan dengan penyakit dalam kapal yang dipertanggungkan, dalam hal disinfeksi, bahan bakar atau penyeretan dan port perlindungan; 4. Pengalihan; 5. Repatriasi and Forwarding; 6. Efek Pribadi; 7. Kompensasi Kerugian Total Kru; 8. Tabrakan: dan kewajiban setelah tabrakan dengan kapal lain; 9. Kerusakan properti: kewajiban untuk biaya insidentil yang timbul dari dan kerusakan atau kompensasi atas pelanggaran hak-hak sehubungan dengan objek tetap dan mengambang, kerusakan tabrakan non properti lain; 10. Polusi: biaya yang berkaitan dengan insiden yang mengakibatkan pencemaran, kerusakan; 11. Penyelamatan: kompensasi untuk kapal penyelamat; 12. Akomodasi dan Pemeliharaan: biaya kapal berikut api, tabrakan, terdampar atau kontak dengan zat lain selain air; 13. Penyeretan dari kapal tertanggung: biaya insidentil dari tertanggung yang timbul dari kontrak untuk penyeretan dari kapal tertanggung; 14. Penyeretan oleh kapal tertanggung: kewajiban yang timbul dari penyeretan oleh kapal tertanggung; 15 . Kontrak dan ganti rugi; 16. Pembersihan serpihan kapal; 17. Pertanggungjawaban atas isi kargo; 18. Proporsi rata-rata GA; 19 . Biaya proporsi rata-rata GA tidak dapat dipulihkan di bawah kebijakan hull; 20. Denda dan penalti; 21. Enquiry; 22. Biaya shipowning insidentil: biaya insidentil untuk bisnis memiliki, mengoperasikan atau mengelola kapal; 23. Biaya \& biaya dalam hubungannya dengan minimisasi rugi; 24. Biaya sehubungan dengan stowaways dan pengungsi; 25. Biaya hukum. Ketentuan di atas sebagaimana di atur dalam Institute Time Clauses-Hulls 1.10.83 Clause 280.

Memahami penjelasan di atas, dapat diketahui bahwa pemenuhan akan unsur-unsur yang dijabarkan dalam UU Pelayaran maupun BW akan hak hak yang mesti didahulukan atau privilege juga merupakan hal yang tertanggung oleh asuransi. Maka bilamana kreditor privilege menuntut hak privilegenya, dan meskipun tidak menuntut haknya untuk didahulukan, pembayarannya ditanggung oleh perusahaan asuransi, tentunya sesuai paket asuransi yang menyediakan fasilitas untuk itu.
Berdasarkan uraian ini, dapat dipahami bahwa kreditor pemegang hipotek sebagai seorang kreditor hak kebendaan, mempunyai sifat preferensi yang begitu hebatnya dan terlahir dari beberapa ketentuan perundang-undangan, bilamana berbenturan dengan kreditor privilege yang juga terlahir dari peraturan perundangan yang sama, maka pada saat itu kreditor pemegang hipotek dapat kehilangan preferensinya dalam hal mendapatkan pelunasan hutang. Hal ini hanya sebatas bila hak privilege itu diajukan.

Begitu pula dari cara kreditor pemegang hipotek dan kreditor privilege ini mendapatkan dana. Berbeda antara dana hasil santunan asuransi ataupun dana hasil proses penjualan. Perbedaanya ada pada jumlah dana yang kemungkinannya berlebih, atau bahkan dana yang kemungkinannya kurang mencukupi setelah hasil pelelangan atau penjualan. Untuk menghindari kekurangan ini, dan juga mengantisipasi tagihan yang mungkin juga besar dari kreditor privilege, maka kreditor hipotek sebelum dapat memberikan pinjaman sepatutnya dengan menilai harga pasar obyek yang akan dibebani hipotek dan menetapkan nilai hipotek lebih besar dari besar hutangnya. Kreditor hipotek tidaklah perlu melihat langsung obyek yang akan dijaminkan, namun perlu juga untuk mempelajari dokumen pendaftaran kapal yang akan di hipotekkan. Pemberian hipotek tentunya tidak seharga obyek yang akan dihipotekkan, namun sebesar $50-60 \%$ dari nilai obyek yang akan dijaminkan. Kreditor menetapkan nilai penjaminan hipotek selain untuk menjamin pelunasan dari pinjaman debitor juga dimaksudkan dapat menutup bunga berjalan, denda keterlambatan pembayaran, biaya perkara dan lainnya.

\section{PENUTUP \\ Kesimpulan}

Bilamana suatu obyek hipotek musnah, sudah seyogyanya kreditor hipotek itu berubah menjadi kreditor konkuren, namun sifat pelunasan hutangnya tetap didahulukan (memiliki sifat preferensi) karena adanya janji-janji dalam SKMH. Kreditor pemegang hipotek sebagai kreditor preferen dan merupakan kreditor hak kebendaan yang mempunyai sifat sangat istimewa ternyata mempunyai kelemahan tentang hak untuk didahulukan pembayaran hutangnya ketika berbenturan dengan pihak kreditor privilege. Kreditor privilege yang diatur dalam BW, KUHD dan UU Pelayaran ini dapat mendapatkan hak privilegenya hanya ketika hak itu diminta/diajukan/didaftarkan, dan pada saat itu maka bila berhadapan dengan kreditor preferen pemegang hak kebendaan, maka kreditor hak kebendaan itu akan kehilangan preferensinya untuk 
didahulukan pelunasan hutangnya dari cara apapun, baik dari hasil lelang ataupun hasil santunan asuransi, ataupun dengan cara normal. Bertalian dengan cara pelunasan hutang hipotek antara lain dengan lelang atau melalui santunan asuransi, terdapat perbedaan akan jumlah dana, bila dari santunan asuransi, asuransi hanya akan membayar seperlunya dan tidak akan ada kelebihan dana, sebaliknya, dari hasil lelang, dapatlah dihasilkan jumlah dana yang lebih setelah digunakan untuk membayar para kreditor. Dan juga dimungkinkan untuk terjadi kekurangan dana setelah proses lelang atau jual, namun itu tidak serta-merta membuat kreditor hipotek menjadi kreditor konkuren. Hal ini terjadi karena hipotek hanya sebagai pelunasan hutang saja, dan akan terus melekat bila nilai hutang belum terpenuhi semua.

\section{Rekomendasi}

Dengan memahami dan mengetahui bahwa ketentuan hipotek yang ada saat ini sungguh tersebar baik dalam BW, KUHD ataupun dalam UU Pelayaran, baik itu meliputi aspek apa saja termasuk asuransi, pembayaran hutang, dan juga macam-macam kreditornya dan tingkatannya, maka perlulah dibuat satu unifikasi hukum mengenai hipotek yang memuat seluruh ketentuan hipotek. Contohnya dalam hal ini adakah benturan kreditor privilege dengan kreditor preferen, maka bila berdasar undang-undang, kreditor privilege menang, namun belum tentu khalayak mengetahui akan hal ini, akan eksistensi dari kreditor privilege, maka dari itu, adalah suatu hal yang sangan membantu Indonesia dalam perkembangan bisnis pelayaran, bila terdapat suatu unifikasi hukum mengenai hipotek, yang mana nantinya pengaturan akan hipotek itu dapat menjadi lebih jelas, terarah, dan dapat dipahamai berbagai kalangan masyarakat, dan tidak hanya kalangan hukum saja.

\section{DAFTAR PUSTAKA}

Buku:

Agoes, Etty R., 1991, Konvensi Hukum Laut 1982 dan Masalah Pengaturan Hak Lintas Kapal Asing, Bandung: Abardin.

Fuady, Munir, 2003, Jaminan Fiducia (Cetakan Kedua Revisi), Bandung: Citra Aditya.

Ginting, Ramlan, 2008, Tinjauan tentang Hipotek Kapal, Buletin Hukum Perbankan dan Kebanksentralan.

H.S.,Salim, 2004, Perkembangan Hukum Jaminan di Indonesia, Jakarta: Raja Grafindo Persada.

Hartono, Sri Rejeki, 1995, Hukum Asuransi dan Perusahaan Asuransi, Jakarta: Sinar Grafika.
Hernoko, Agus Yudha, 2010, Hukum Perjanjian: Asas Proporsionalitas dalam Kontrak Komersial, Jakarta: Kencana.

Isnaeni, Moch., 1996, Hipotek Pesawat Udara di Indonesia, Surabaya: Dharma Muda.

Kaihatu, J. E., 1995, Asuransi Pengangkutan, Jakarta: Djambatan.

Purba, Radiks, 1998, Asuransi Angkutan Laut, Jakarta: RinekaCipta.

Satrio, J., 1996, Hukum Jaminan Hak-Hak Kebendaan, Bandung: Citra Aditya Bakti. 2005, Hukum Jaminan Kebendaan Fidusia, Bandung: Citra Aditya Bakti.

Simamora, Sogar, 2010, Hukum Perjanjian Prinsip Hukum Kontrak Barang dan Jasa, Yogyakarta: LaksBangPRESSindo.

Sofwan, Sri Soedewi, 1982, Himpunan Karya tentang Hukum Jaminan, Yogyakarta: Liberty. , 1980, Hukum Jaminan di Indonesia: PokokPokok Hukum Jaminan dan Jaminan Perorangan, Yogyakarta: Liberty Offset.

Subekti dan Tjitrosudibio, 2004, KUHP (Burgerlijk Wetboek), Jakarta: Pradnya Paramita.

Subekti, 2003, Pokok-Pokok Hukum Perdata, Bandung: Intermasa.

Suryodiningrat, RM, 1991, Perikatan-Perikatan Bersumber Perjanjian, Bandung: Tarsito.

Sutjipto, 1996, Pendaftaran dan Balik Nama Kapal Panduan bagi Pejabat Pendaftaran Kapal, Jakarta: Pradnya Paramita.

Widjaja, Gunawan, 2005, Hak Istimewa, Gadai, \& Hipotek, Jakarta: Prenada Media.

\section{Peraturan Perundang-undangan:}

Undang-Undang No. 21 Tahun 1992 tentang Perkapalan.

Undang-Undang No. 4 Tahun 1996 tentang Hak Tanggungan.

Undang-Undang No. 17 Tahun 2008 tentang Pelayaran.

\section{Internet:}

Kusumadewi, Anggi, 5 Kecelakaan Kapal Dalam Sebulan, http://nasional.vivanews.com/news/ $\mathrm{read} / 2580815$-sebulan-ada-5-kecelakaan-kapalsalah-siapa.

Musjab, Imam, Asuransi Kapal Laut Marine and Hull, http://ahliasuransi.com/asuramsi.com/asuransikapal-dan-pi-marine-hull-and-pi/

, Asuransi Kapal Laut P\&I Protection, http: //ahliasuransi.com/protection-indemnity-piinsurance-quotation/ 